\title{
Histopathological Alterations In Organs of Nile Tilapia Fingerlings Exposed To Sub- Lethal Concentrations of Aqueous Crude Leaves Extract of Desert Date
}

\section{Bala S. Audu , Idi A. Wakawa*, Jamiu O. Omirinde3, Usman Garba4, Mar- garet Damshit ${ }^{1}$}

${ }^{1}$ Hydrobiology and Fisheries Unit, Department of Zoology, University of Jos, Jos, Nigeria

${ }^{2}$ Department of Biology, Umar Suleiman College of Education, Gashua, Yobe State, Nigeria

3Departmnet of Anatomy, Faculty of Veterinary Medicine, University of Jos. Jos, Nigeria

4Federal Department of Fisheries, 1, Wilmot Point Road, Ahmadu Bello Way, Victoria Island, Lagos, Nigeria

*Correspondence should be addressed to Idi A. Wakawa : idrisswakawa2015@gmail.com

Received 2nd July 2020; Revised 23rd July 2020; Accepted 25th July 2020

(C) 2020 Audu et al. Licensee Pan African Journal of Life Sciences. This is an Open Access article distributed under the terms of the Creative commons Attribution License (https://creativecommons.org/licenses/BY/4.0), which permits unrestricted use, distribution, and reproduction in any medium, provided the original work is properly cited.

\begin{abstract}
Background: Histopathological changes have been widely used as biomarkers in determining the effects of pollutants on fish. Leaves of Balanites aegyptiaca, a deep-rooted, evergreen or semi-deciduous, multibranched, spiny tree have been reported to have pesticidal, anaesthetic and ichthyotoxic effects. This study sought to find out the effect of sub-lethal concentrations (5.00, 11.00, 21.00, 43.00, and 86.00 mg/L) of B. aegyptiaca on histopathology of gills, kidney, and liver of mixed-sex Oreochromis niloticus fingerlings

Methods: A total of $120 \mathrm{O}$. niloticus fingerlings (mean weight $23 \pm 0.03 \mathrm{~g}$ and mean total length $12.50 \pm 0.39 \mathrm{~cm}$ ) were exposed to aqueous crude leaves extract of B. aegyptiaca. The gills, kidney, and liver were excised and processed routinely for the elucidation of histopathological changes

Results: Dose-dependent histopathological changes were observed in the three organs (gills, kidney and liver) of $O$. niloticus exposed to graded concentrations of $B$. aegyptiaca. Gills showed moderate to severe secondary lamellae fusion, desquamation, and primary lamellae congestion while the kidney displayed mild to severe renal tubular epithelial cell degeneration and necrosis as well as pigmentation of renal tissues. The liver showed varying degrees of histo-architectural alterations such as hepatocellular degeneration and necrosis, cellular infiltrations, kupffer cell proliferation, portal, and sinusoidal congestions
\end{abstract}

Conclusion: Owing to these histological alterations in the gills, kidney, and liver observed in this study, prolonged exposure of fish to B. aegyptiaca should be discouraged to preserve fish diversity

Keywords: Histopathology, Sub-lethal, Balanites aegyptiaca, Oreochromis niloticus 


\subsection{INTRODUCTION}

The indiscriminate deposition of pollutants into lentic and lotic waters by anthropogenic activities is posing a momentous threat to the aquatic environment and causing high risk to fish and other aquatic fauna [1]. Some of the main surfaces exposing fish to aquatic toxicants are gills, kidney, and liver due to their role in respiration, osmoregulation, excretion, and depuration [1] as well as detoxification and biotransformation [2].

Balanites aegyptiaca, commonly called desert date, soapberry tree, Egyptian balsam or thorn tree [3] has been reported to have pesticidal [4], anaesthetic [5] and ichthyotoxic or piscicidal $[6,7]$ effects. Nkunya et al., [8] had earlier reported stem bark of $B$. aegyptiaca as a fish poison and thus been used to catch fish in lentic and lotic waters around the globe $[9,7]$. Nigerians are not left out in the use of plant materials for fishing [10].

Histopathological studies of fish organs after exposure to toxicants have been used to assess disease problems [11]. Many authors have reported the effect of plant extracts on histopathology of organs of fish. Akinsanya et al., [12] reported histopathological alterations (proliferation of tissue, congestion of blood vessel, complete fusion of lamellae and lifting of epithelia) in gills of C. gariepinus after exposure to seven rich plant extracts (Piper guineense, Aframomum melegueta, Moringa oleifera, Gongronema latifolium, Azadirachta indica, Garcinia kola and Xylopia aethiopica). Audu et al., [13] reported histo-architectural distortions (hepatocellular degeneration; central and sinusoidal congestions) in the liver of C. gariepinus exposed to concentrations of Vernonia amygdalina. In the same vein Abalaka et al., [14] had earlier reported hyperaemia and severe oedema with fusion of lamellae in the gills of Clarias gariepinus exposed to ethanol extract of Adenium obesum stem bark. Nasiruddin et al., [15] also reported disintegration of gill filaments and lamellae, degeneration of hepatocytes and blood vessels and necrosis of the intestinal epithelia of Heteropneustes fossilis exposed to $50 \%$ ethyl alcohol extract of three dry seed extracts (Lagerstroemia speciosa, Dipterocarpus turbinatus, and Hevea brasiliensis). In addition, Oluwatoyin [10] reported necrosis, cellular degeneration, malignancy and inflammation on the gills after exposure of $O$. niloticus to concentrations of Ipomoea aquatica.

From the available literature, there is a paucity of data on the effects of sub-lethal concentrations of aqueous crude leaves extracts of B. aegyptiaca on fish organs. This study, therefore, sought to find out the effects of sub-lethal concentrations of aqueous crude leaves extract of $B$. aegyptiaca on histology of gills, kidney, and liver of mixed-sex $O$. niloticus.

\subsection{METHODOLOGY}

\subsection{Preparation of $B$. aegyptiaca Leaves}

Fresh leaves of $B$. aegyptiaca (identified in the Department of Plant Science and Technology, Faculty of Natural Sciences, University of Jos, Nigeria with voucher no. JUHN2000323) were collected from Gashua, Bade Local Government Area of Yobe State, Nigeria. The leaves washed with clean water several times to remove soil, dust, and other dirt. A quantity of $3 \mathrm{~kg}$ was shade dried, pulverized with pestle and mortar and sieved (0.5 $\mathrm{mm}$ sieve) into fine powder [12] before storing in airtight plastic containers

\subsection{Acclimation of the Experimental Fish}

A total of 120 mixed-sex $O$. niloticus fingerlings were purchased from Alpaks Fish Farm, Rantia, Jos, Plateau State, Nigeria. They were transported in two oxygenated polythene bags (6o fingerlings per bag) to Aquaculture Laboratory of Hydrobiology and Fisheries Unit of University of Jos, Jos, Nigeria. Two weeks before the experiment, fish were acclimated in six 35 L capacity round plastic containers (20 fingerlings per container) filled with $20 \mathrm{~L}$ of water. Fish were fed to satiation with an artificial diet (Coppens ${ }^{\circledR}$ ) twice daily at 10.00 and 17.00 hours, Nigerian time. The water of the holding tanks was changed once every day at 8.00 hours to reduce pollution caused by uneaten feed and faecal matter

\subsection{Experimental Design}

The experiment consists of six rectangular glass tanks (40 x $25 \times 3 \mathrm{~cm}$ ) labeled A-F containing sixty O. niloticus fingerlings (10 fingerlings/tank), mean weight $23.13 \pm 2.43 \mathrm{~g}$ and mean total length $12.50 \pm 0.39 \mathrm{~cm}$ randomly arranged with six treatments and two replicates [16]. Each of the glass tanks was filled with 10 $\mathrm{L}$ of dechlorinated municipal tap water; five of the filled tanks (B-F) were inoculated with various concentrations of aqueous crude leaves extract of $B$. aegyptiaca and 10 mixed sex $O$. niloticus fingerlings were introduced into each. The other tank (A), which served as control, was also stocked with 10 of the fingerlings but was not inoculated with the test material. The entire setup was duplicate replicated.

\subsection{Monitoring Water Quality Parameters}

Water quality parameters such as temperature, dissolved oxygen (DO), free carbon dioxide $\left(\mathrm{CO}_{2}\right)$, total alkalinity 
(TA), hydrogen ion concentration ( $\mathrm{pH})$, total hardness (TH), total ammonia (TAm) and nitrite of the experimental tanks were monitored using the standard methods of American Public health association (APHA) [17] while APHA [18] was used to monitor total hardness every $24 \mathrm{hr}$ for 56 days.

\subsection{Exposure of $O$. niloticus Fingerlings}

Exactly 60 mixed-sex $O$. niloticus fingerlings were randomly introduced into 5 tanks (10 fingerlings per test tank) containing 5.00 (B), 11.00 (C), 21.00 (D), 43.00 (E), and $86.00 \mathrm{mg} / \mathrm{L}(\mathrm{F})$ [determined by multiplying the earlier calculated $\mathrm{LC}_{50}$ value (257.04) by $1 / 48,1 / 24,1 / 12$, $1 / 6$, and 1/3] concentrations of aqueous crude leaves extract of B. aegyptiaca. The sixth tank (control; A) was not inoculated with the plant material but 10 mixed-sex $O$. niloticus fingerlings were introduced into it and setup replicated. The fingerlings were exposed to the treatment (B-F) and the control (0.00 mg/L; A) for 56 days. The test material was renewed every 7 days. The oxygen supply was boosted by constant aeration with air compressor model ACO-308 throughout the experiment

\subsection{Excision of Organs of O. niloticus Fingerlings}

After exposure of the mixed-sex $O$. niloticus fingerlings to sub-lethal concentrations of aqueous crude leaves extract of $B$. aegyptiaca, two fingerlings (one each from treatment and control tanks) were removed and dissected to extract the gills, liver, and kidney. Each excised organ was rinsed with distilled water to wash off traces of blood and preserved in $10 \mathrm{ml}$ specimen bottle containing $5 \mathrm{ml}$ formal saline before histopathological examinations was conducted at the National Veterinary Research Institute (NVRI), Vom; Plateau State, Nigeria

\subsection{Histopathological Examination of Gills, kidney and Liver of $O$. niloticus Fingerlings}

Paraffin wax method and hematoxylin-eosin staining techniques of tissue processing described by Drury and Wallington [19] and Avwioro [20] were adopted for the examination of the gills, kidney and liver of $O$. niloticus fingerlings exposed to aqueous crude leaves extract of $B$. aegyptiaca.

\subsection{Data Analysis}

Statistical analysis was performed using IBM SPSS (version 20) software. Data were analyzed by one-way of variance analysis (ANOVA). Treatment means were separated using Tukey's multiple comparisons test. Level of significance was determined at $\mathrm{p}<0.05$ level of probability.

\subsection{RESULTS}

\subsection{Water Quality Parameters of Experimental Tanks}

The water quality parameters results are summarized in Table 1. There was no significant difference $(\mathrm{p}=2.24)$ in the levels of $\mathrm{DO}$, temperature, $\mathrm{pH}$, free $\mathrm{CO}_{2}$, TA, TAm, and nitrite in the water of tank containing $O$. niloticus exposed to graded concentrations of $B$. aegyptiaca compared to the control. Although there were progressive concentration-related insignificant alterations (increase

Table 1. Water Quality Parameters of Experimental Tanks during Sub-Lethal Toxicity Test of $O$. niloticus Fingerlings with Aqueous Crude Leaves Extract of $B$. aegyptiaca

\begin{tabular}{|c|c|c|c|c|c|c|c|}
\hline \multirow[t]{2}{*}{ Water Quality Parameters } & \multicolumn{7}{|c|}{ Concentrations (mg/L) } \\
\hline & 0.000 & 5.00 & 11.00 & 21.00 & 43.00 & 86.00 & P value \\
\hline DO (mg/L) & $5.41 \pm 0.32$ & $4.76 \pm 0.46$ & $4.46 \pm 0.46$ & $4.14 \pm 0.45$ & $4.03 \pm 0.56$ & $3.99 \pm 0.45$ & 0.320 \\
\hline Temp (oC) & $23.13 \pm 0.30$ & $23.13 \pm 0.30$ & $23.13 \pm 0.30$ & $23.13 \pm 0.30$ & $23.13 \pm 0.30$ & $23.13 \pm 0.30$ & 0.850 \\
\hline $\mathbf{p H}$ & $7.24 \pm 0.12$ & $7.02 \pm 0.15$ & $6.93 \pm 0.16$ & $6.76 \pm 0.12$ & $6.74 \pm 0.10$ & $6.62 \pm 0.10^{*}$ & 0.713 \\
\hline Free $\mathrm{CO}_{2}(\mathrm{mg} / \mathrm{L})$ & $12.75 \pm 1.76$ & $13.75 \pm 1.53$ & $14.25 \pm 1.99$ & $14.25 \pm 1.20$ & $14.50 \pm 1.31$ & $16.25 \pm 1.82$ & 0.550 \\
\hline TA (mg/L) & $54.00 \pm 5.64$ & $58.25 \pm 5.60$ & $58.38 \pm 6.62$ & $60.75 \pm 5.69$ & $60.75 \pm 4.78$ & $63.13 \pm 5.99$ & 0.035 \\
\hline TH (mg/L) & $\begin{array}{l}20.00 \pm 0.0 \\
0\end{array}$ & $20.90 \pm 0.10^{*}$ & $22.40 \pm 0.15^{*}$ & $21.90 \pm 0.09^{*}$ & $22.00 \pm 0.06^{*}$ & $21.65 \pm 0.09^{*}$ & 0.420 \\
\hline TAm (mg/L) & $0.03 \pm 0.01$ & $0.03 \pm 0.01$ & $0.04 \pm 0.01$ & $0.04 \pm 0.00$ & $0.04 \pm 0.01$ & $0.05 \pm 0.00$ & 0.480 \\
\hline Nitrite (mg/L) & $0.01 \pm 0.00$ & $0.01 \pm 0.00$ & $0.01 \pm 0.00$ & $0.02 \pm 0.00$ & $0.02 \pm 0.00$ & $0.02 \pm 0.00$ & 0.630 \\
\hline
\end{tabular}


or decrease) (p>0.05) in the levels of the studied parameters, they were not statistically significant to establish differences. For the total hardness level, there was a significant concentration-dependent increase in its level across the various tanks containing concentrated grades of $B$. aegyptiaca relative to the control.

\subsection{Histopathology of Gills of $O$. niloticus Finger- lings}

The histopathological results of gill of $O$. niloticus exposed to sub-lethal concentrations of aqueous crude leaves extract of $B$. aegyptiaca are shown in Plate 1. The gill of the control fish was characterized by the presence of primary lamellae (F) from which secondary lamellae (L) radiate out and a bony framework, ceratobranchial bone of the arch (C). Conversely, the gill of O. niloticus exposed to grades of B. aegyptiaca extract displayed progressive concentration-dependent gill histo-architectural distortions characterized by moderate to severe lamellar fusion, desquamation of lamellar parenchyma cells, interlamellar occlusion, secondary lamellar clubbing, and lamellar vascular congestion. The severity of the lesions appeared to be more conspicuous in the gill architecture of fish exposed to the higher concentrations $(21,43$, and $86 \mathrm{mg} / \mathrm{L}$ ) of the extract when compared to others. However, the gill histoarchitecture in the fish exposed to the lower concentration $(5 \mathrm{mg} / \mathrm{L})$ of $B$. aegyptiaca was not different from that of the control.

\subsection{Histopathology of Kidney of $O$. niloticus Fin- gerlings}

The kidneys' photomicrographs of $O$. niloticus exposed to sub-lethal concentrations of aqueous crude leaves extract of B. aegyptiaca are presented in Plate 2. The kidney parenchyma in the control fish is typified by intact renal tubules (star) and renal glomerula substance (G) within the Bowman's capsule (white arrow) that is separated by urinary space (asterick) as well as clearly defined hematopoietic tissue (HT). However, in groups exposed to graded concentrations of $B$. aegyptiaca, there were concentration related damages to the kidney histo-architecture featuring as moderate to severe renal tubular epithelial cell degeneration and necrosis (cellular depletion), renal interstitial congestion, haematopoietic tissue hyperplasia, glomerula depletion and renal interstitial pigmentation. The similar severity pattern observed for gill was observed for the kidney parenchyma of $O$. niloticus with most remarkable damage seen in the fish exposed to the higher concentrations $(21,43$ and $86 \mathrm{mg} / \mathrm{L}$ ) of the extract compared to others .

\subsection{Histopathology of Liver of $O$. niloticus Finger- lings}

The histopathological lesions observed in the liver of $O$.
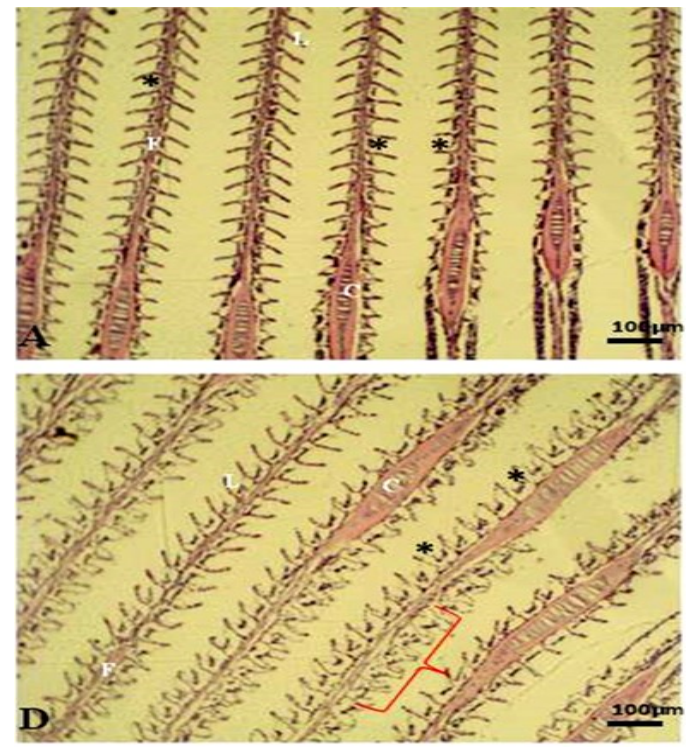
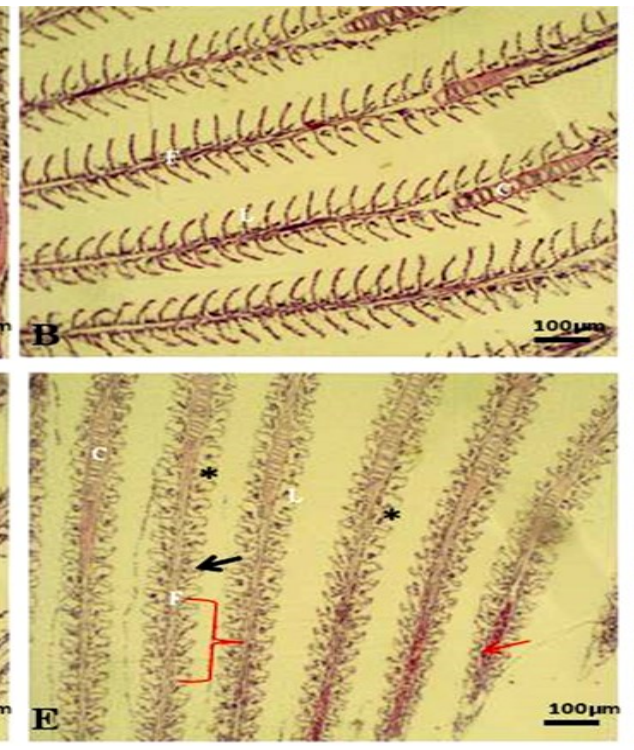
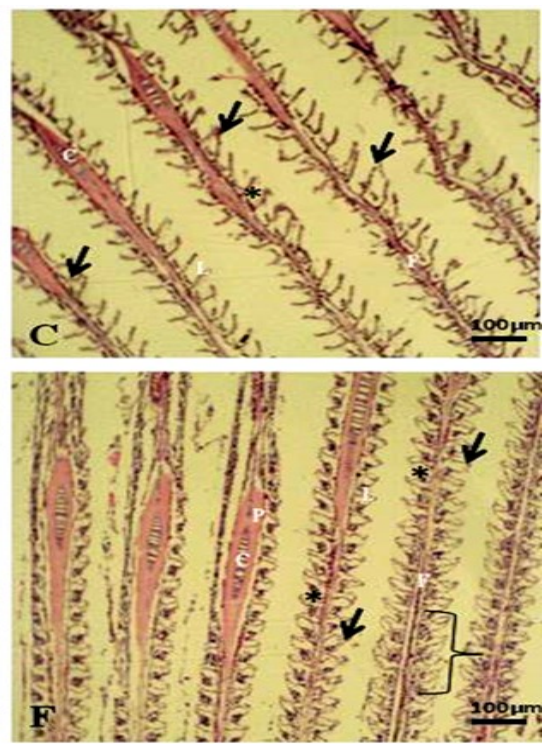

Plate 1. Gills of O. niloticus exposed to Sub-Lethal Concentrations of Aqueous Crude Leaves Extract of B. aegyptiaca.

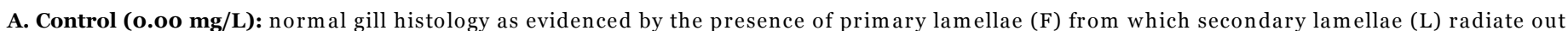

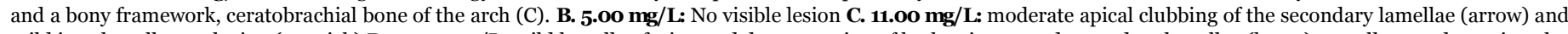

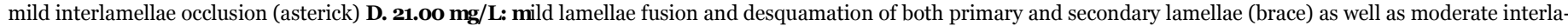

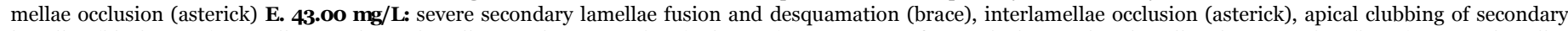

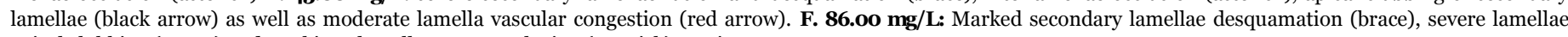
apical clubbing (arrow) and total interlamellae space occlusion (asterick). Stain: H\&E
} 

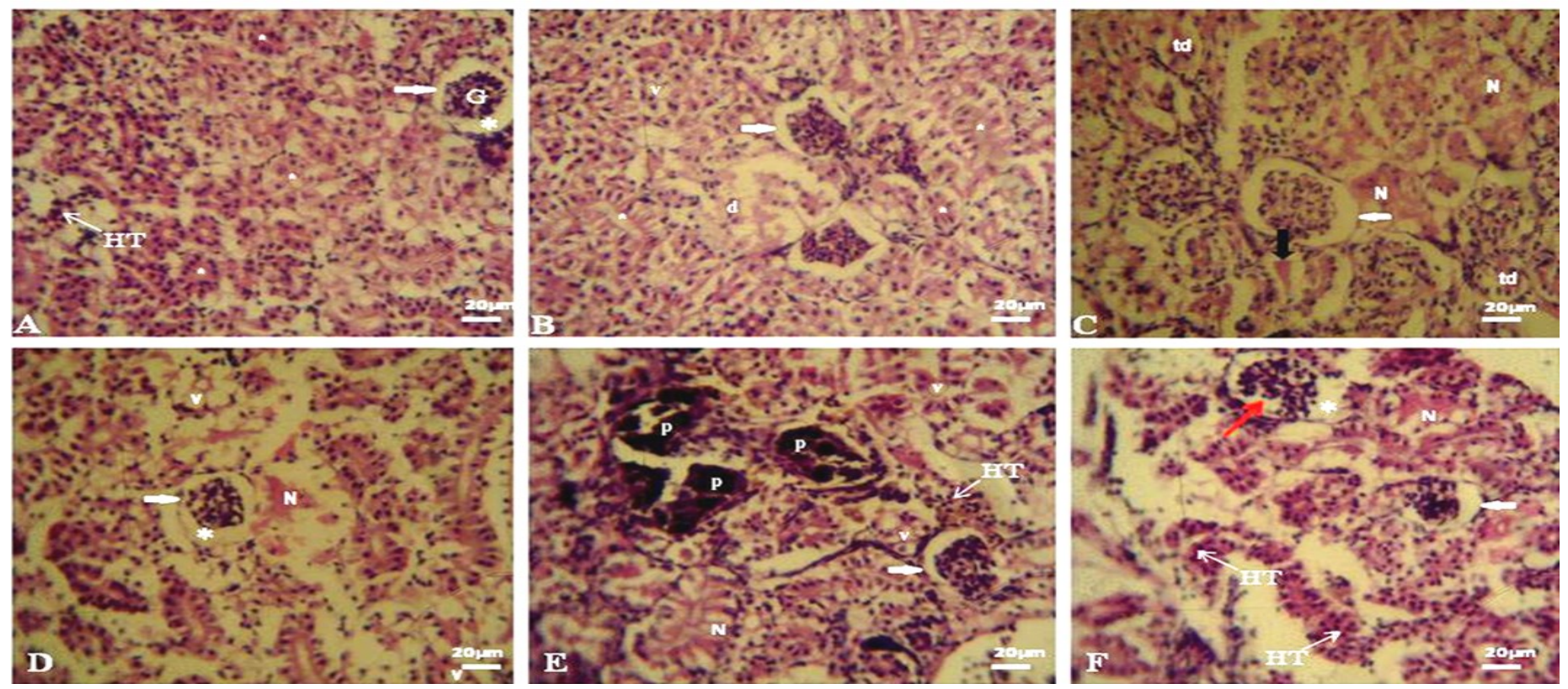

Plate 2. Kidney of $O$. niloticus exposed to Sub-Lethal Concentrations of of Aqueous Crude Leaves Extract of $B$. aegyptiaca.

\begin{abstract}
A. Control (o.oo mg/L): Normal renal parenchyma as typified by intact renal tubules (star) and renal glomerula substance (G) within the Bowman's capsule (white arrow) that is separated by urinary space (asterick) as well as clearly defined hematopoietic tissue (HT) B. 5.0o mg/L: Mild renal tubular epithelial cell degeneration (d) characterized by moderate renal cell vacuolations (v). C. 11.0o mg/L: Moderate renal tubular necrosis (N) and tubular epithelial degeneration (td) coupled with mild renal interstitial congestion (black arrow) $\mathbf{D} . \mathbf{2 1 . 0 0} \mathbf{~ m g} / \mathbf{L}$ : mild shrinkage of glomerula substance (arrow) with increased urinary space (asterick) and severe renal tubular epithelial cells depletion/necrosis $(\mathrm{N})$ and tubular cell degeneration characterized by marked vacuolations (v) E. 43.0o mg/L: Severe renal tubular epithelial depletion/necrosis (N), marked renal interstitial pigmentation (P) and moderate hyperplasia of hematopoietic tissue (HT) F. 86.oo mg/L: Focal depletion of glomerula substance (red arrow), mildly increased urinary space (asterick), marked hematopoietic tissue hyperplasia (HT) and severe renal tubular epithelial cell depletion/necrosis (N). Stain: H\&E
\end{abstract}

niloticus exposed to sub-lethal concentrations of aqueous crude leaves extract of $B$. aegyptiaca are presented in Plate 3. The histological features of the liver in the control fish include; hepatocytes bearing intact outline (polyhedral shape), roundish nuclear (arrow) appearance and normal sinusoids (star). On the other hand, the liver of $O$. niloticus groups exposed to different concentrations of $B$. aegyptiaca showed moderate to severe concentration-dependent histopathological lesions characterized by cellular infiltration, hepatocellular degeneration and necrosis, as well as Kupffer cell proliferation. The hepatocel- lular damage seemed to be striking in the groups exposed to the higher concentrations (21, 43 and $86 \mathrm{mg} / \mathrm{L}$ ) of the extract. Summary of histopathological changes in gills, kidney and liver of $O$. niloticus fingerlings is presented in Table 2

\section{4.o DISCUSSION}

The study of water quality parameters in aquatic toxicology is necessary owing to its role in the survival of aquatic organisms [21] since the entire life process of fish is wholly dependent on its environment [22]. The non-

Table 2. Sum mary of Histopathological Alterations in Organs of O. niloticus Fingerlings

\begin{tabular}{|c|c|c|c|c|c|c|c|c|c|c|c|c|c|c|c|c|}
\hline \multirow{3}{*}{$\begin{array}{l}\text { Conc } \\
\text { (mgL) }\end{array}$} & \multicolumn{16}{|c|}{ HISTOPATHOLOGICAL LESIONS } \\
\hline & \multicolumn{5}{|c|}{ GILL } & \multicolumn{4}{|c|}{ KIDNEY } & \multicolumn{7}{|c|}{ LIVER } \\
\hline & $\mathrm{AC} / \mathrm{F}$ & $\mathrm{IO}$ & $\mathrm{LC}$ & $\mathrm{LD}$ & $\mathrm{HH}$ & $\mathrm{RD}$ & IP & GD & $\mathrm{IC}$ & $\mathrm{TD} / \mathrm{N}$ & $\mathrm{SC}$ & $\mathrm{PC}$ & $\mathrm{CI}$ & $\mathrm{HN} / \mathrm{D}$ & $\mathrm{KP}$ & $\mathrm{HD}$ \\
\hline 0.00 & - & - & - & - & - & - & - & - & - & - & - & - & - & - & - & - \\
\hline 5.00 & - & - & - & - & - & + & - & - & - & - & + & + & - & - & - & + \\
\hline 11.00 & - & - & - & - & - & + & - & - & + & + & - & - & + & - & - & + \\
\hline 21.00 & + & + & - & + & - & - & - & - & - & + & - & - & - & - & + & + \\
\hline 43.00 & ++ & ++ & + & ++ & ++ & - & ++ & - & - & - & - & - & - & + & ++ & ++ \\
\hline 86.00 & ++ & ++ & - & ++ & ++ & - & - & + & - & ++ & - & - & - & ++ & + & - \\
\hline
\end{tabular}

AC/F - Lamellae clubbing/fusion, IO - Interlamella occlusion, LC - Lamellar congestion, LD - Lamellar desquamation, HH - Hematopoietic tissue hyperplasia, RDRenal tubular cell degeneration, IP - Interstitial pigmentation, GD- Glomerula depletion, IC- Interstitial congestion, TD/N - Tubular Depletion/necrosis, SC - Sinusoidal congestion, PC- Portal congestion, CI - Hepatocellular infiltration, HN/D - Hepatocellular necrosis/ Depletion, KP - Kupffer cell proliferation, HD - Hepatocellular degeneration. + (Presence); ++ (Severe Presence); - (Absence). 

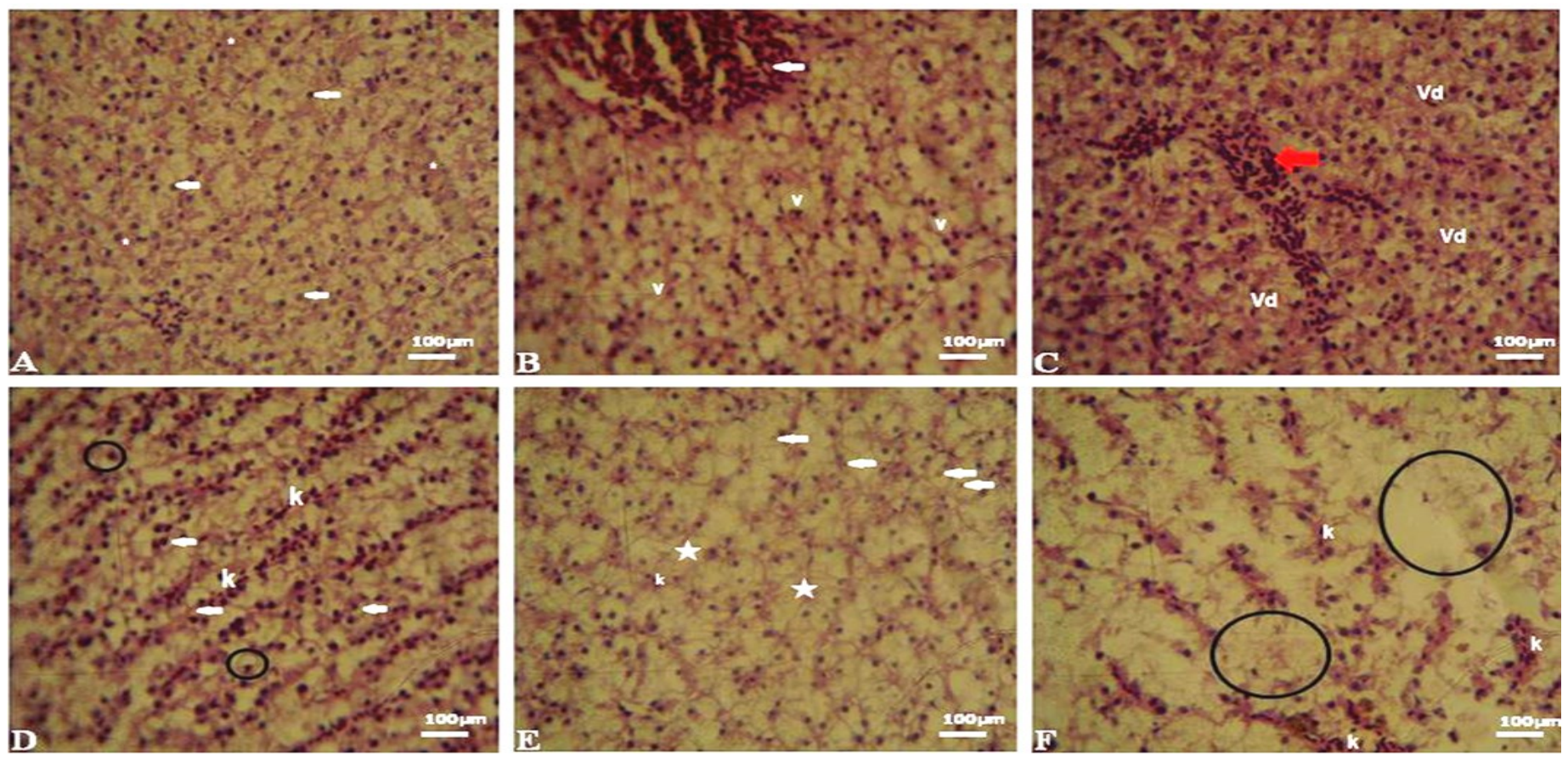

Plate 3. Liver of $O$. niloticus Exposed to Sub-Lethal Concentrations of Aqueous Crude Leaves Extract of B. aegyptiaca for 56 Days Sub-Lethal Toxicity Test showing:

\begin{abstract}
A. Control (o.oo mg/L): Normal hepatic parenchyma as revealed by hepatocytes with intact outline (polyhedral shape), roundish nuclear (arrow) and cytoplasmic appearances and normal sinusoids (star). B. 5.00 mg/L: the liver parenchyma bears moderate portal congestion (white arrow) and mild hepatocytes nuclear and cytoplasmic degeneration (V) C. 11.0o mg/L: Moderate cellular infiltration and mild nuclear and cytoplasmic hepatic degeneration (Vd) D. 21.0o $\mathbf{~ m g / L : ~}$ Marked Kupffer Cell Proliferation (k), moderate hepatocellular degenerations manifesting as progressive loss of hepatocytes cellular outline (circle-outline), nuclear degeneration and cytoplasmic vacuolation (white arrow) E. 43.00 mg/L: Severe hepatocellular degeneration (white arrow) with mild foci of hepatocellular necrosis (star) and mild Kupffer Cell Proliferation (k) F. 86.0o mg/L: Severe hepatocellular necrosis with almost complete hepatocellular depletion (circle outline) and mild Kupffer Cell

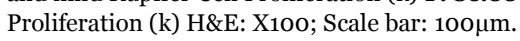

significant alterations (increase/decrease) in the levels of $\mathrm{DO}$, temperature, $\mathrm{pH}$, free $\mathrm{CO}_{2}, \mathrm{TH}, \mathrm{TAm}$, and nitrite in the water laden with concentrated grades of B. aegyptiaca could be due to degrading effect of the leaves extract on the oxygen molecules [23]. This result is similar to the findings of Kasi et al., [24] and Audu et al., [25]. Though there was a decreasing trend in DO as leaves extract concentration increased, it could not have been responsible for the changes in physiology and histology of the fingerlings since it was within the normal DO tolerance level of 3-4 mg/L [26]. Similarly, the significant variation between the mean $\mathrm{pH}$ of treatments and the control could not have influenced the physiological changes observed in the fingerlings since the mean $\mathrm{pH}$ of all the tanks in this study were within normal (6-8) range [27, 21]. All exposure tanks in this work maintained the same mean temperature with the control, which is similar to the results of Ajima et al., [28] and Alhou et al., [29]. The temperature could not have been a factor in the histological changes observed in the exposed fingerlings since O. niloticus prefer temperatures between 20 and $35^{\circ} \mathrm{C}$ [30]. The observed significant increase in total alkalinity level with increasing concentrations of B. aegyptiaca is suggestive of the productivity of the water. An increase in TA and free $\mathrm{CO}_{2}$ with a concentration of leaves extract in this study is in line with the findings of Becker et al., [31]. The TA in this study is within the normal range of $5^{-}$ $500 \mathrm{mg} / \mathrm{L}$ [21] hence could not be responsible for the observed alterations in the organs of experimental fish.

Histopathological changes are widely used as indicators of the effect of pollutants on fish [32]. Alterations in the gill histological structure could impair blood-water exchange by reducing the surface area of the secondary lamellae directly in contact with the water [32]. Therefore, the moderate to severe gill parenchyma lesions (secondary lamellae fusion and desquamation as well as primary lamellae congestion) seen in this study could have a consequential disruptive effect on the physiology of the gill. The gill histopathological lesions precipitated by graded concentrations of $B$. aegyptiaca were similar to the findings of Abalaka et al., [13] on C. gariepinus exposed to ethanolic extract of Parkia biglobosa, Gulhan et al., [33] on Oncorhyncus mykiss exposed to cypermethrin and Audu et al., [12] on Clarias gariepinus exposed to acute concentrations of Vernonia amygdalina. Oluwatoyin [10] and Adebola and Ayo [34] reported similar necrosis in the gills of $O$. niloticus and Heterobranchus bidorsalis, respectively. Also, the alterations in the gills 
of $O$. niloticus in the present study conform with the findings of Nasiruddin et al., [14] after treating Heteropneustes fossilis with three dry seed extracts. The observed histopathological alterations in the gills of O. niloticus in this study are direct responses to the effects of aqueous crude leaves extract of $B$. aegyptiaca.

The kidney of the teleost is one of the first organs to be affected by environmental contaminants [35] and, more specifically, its renal tubules and glomeruli are the greatly affected components of the kidney [36]. The direct effect of pollutants on the kidneys stemmed from its major roles in the filtering of waste products from the blood before converting it to urine [ 37]. Based on these preambles, the renal histoarchitectural lesions (renal tubular epithelial cell degeneration and necrosis as well as pigmentation of renal tissues) seen in this study portends a great damage to the earlier mentioned functions of kidney and further validates the reno-toxic potential of $B$. aegyptiaca in inducing morpho-physiological derangement to the kidney of $O$. niloticus. The renal histopathological lesions from our work corroborate previous documentations from similar studies on plant extracts (Naeemi et al., [32]; Nasiruddin et al., [14]).

Liver is also one of the most important target organs in fish due to its role in detoxification, biotransformation and excretion of xenobiotics [2]. The liver is reputed to accumulate high concentrations of chemicals than every other organ, including the gill [38]. Hence, the observed dose-dependent histopathological lesions (hepatocellular degeneration and necrosis, cellular infiltrations, kupffer cell proliferation, portal and sinusoidal congestions) are indicators of hepato-toxic effect of the leaves extract of B. aegyptiaca in $O$. niloticus. The hepatic lesions from our work agree with findings documented from similar works on fish exposed to different forms of pollutants [14, 15, 34, 39, 40]. The Kupffer cell proliferation observed may be related to an adaptive mechanism adopted by the fish to overcome the hepatoxic effects of the plant extract.

The histopathological alterations in the gills, kidney, and liver of $O$. niloticus in the present study corroborates the observations of the workers during data collection that local artisanal fishermen in some parts of north eastern Nigeria crush and throw stem bark of $B$. aegyptiaca into lentic waters to easily collect the stupefied fish. Exposure of fish to sub-lethal concentrations of aqueous crude leaves extract of $B$. aegyptiaca for 56 days appeared to be toxic. It is therefore concluded that, exposure of $O$. niloticus fingerlings to sub-lethal concentrations of B. aegyptiaca for 56 days could cause histopathological alterations in the gills, kidney and liver of the fish. The obnoxious use of the aqueous crude stem bark and leaves ex- tracts of $B$. aegyptiaca in lentic water to stupefy fish should be discouraged or regulated, especially amongst the artisanal to safeguard fish abundance and diversity in natural aquatic systems

\section{Conflict of Interest}

The authors declare that there is no conflict of interest.

\section{Authors Contribution}

BSA formulated the topic, created detailed plan of the study, wrote the conclusion and proof read the manuscript; IAW collected data, wrote the introduction, methodology, results and reference sections of the manuscript; JOO analysed and read the photomicrographic plates; UG contributed to the statistical analyses of data; MD contributed to data collection and writing of the discussion section of the manuscript

\section{References}

1. Kumar A, Prasad MR, Srivastava K. Branchial histopathological study of catfish, Heteropneustes fossilis following exposure to purified Neem extract, Azadirachtin. World Journal of Zoology. 2010; 5(4):239-243. www.zoounn.org

2. Olusegun AA, Adedayo OO. Haematological responses, serum biochemistry and histology of Clarias gariepinus (Burchell, 1822) exposed to sub-lethal concentrations of cold water fresh root bark extracts of Plumbago zeylanica (Leadwort). Journal of Aquatic Research and Development. 2014; 5: 282. http://doi.org/10.4174/2155-9546.1000282

3. Chothani DL, Vaghasiya HU. A review on Balanites aegyptiaca Del. (desert date): phytochemical constituents, traditional uses, and pharmacological activity. Pharmacological Review. 2011; 5(9): 55-62. http://doi.org/10.4103/o9737847.79100

4. Hyelda AJ, Effects of feeding graded levels of desert date (B. aegyptiaca) leaves as supplement to the urea treated maize stover on the performance of Red Sokoto goats. Asian Journal of Advances in Agricultural Research. 2017; 2(4):1-10. DOI: 10.9734/AJAAR/2017/36074

5. Wakawa IA, Audu BS, Suleiman Y. Anaesthetic effects of aqueous crude leaf extract of desert date $\backslash$ (Balanites aegyptiaca) on Nile Tilapia (Oreochromis niloticus) fingerlings. International Journal of Fisheries and Aquatic Studies. 2019; 7(1):147-152. www.fisheriesjournal.com

6. Neuwinger HD. Fish poisoning plants in Africa. Botany Acta (Germany). 1994; 107:263-270.

7. Mohotti CRWC, Epa UPC. Toxicity of aqueous extract of white hoary pea, Tephrosia candida (Papilionoideae) on Nile tilapia, Oreochromis niloticus (Cichlidae) fingerlings. Sri Lanka Journal of Aquatic Sciences. 2016; 21(2):105-112 
8. Nkunya MH, Weenen H, Bray DH. Chemical evaluation of Tanzanian medicinal plants for the active constituents as a basis for the medicinal usefulness sof the plants. In KE Mshigeni, MH Nkuanya, V Fupi, RL Mahunnah, EN Mshiu. (Eds.). Proceedings of International Conference on Traditional Medicinal Plants. 1990; Arusha; pp.101-11.

9. Power DM, Fuentes J, Harrison AP. Stunning Fish. Archive of Tierz, Dummerstorf (special Issue). 2008; 51:78-79.

10. Oluwatoyin AS. Histopathology of Nile Tilapia (Oreochromis niloticus) juveniles exposed to aqueous and ethanolic extracts of Ipomoea aquatic leaf. International Journal of Fisheries and Aquaculture. 2011; 3(4):244-257. http://doi.org/10.5897/IJFA11.003

11. Nasiruddin M, Azadi MA,. Nely MS. Histopathological effects of extracts of two indigenous plants, Pongamia pinnata (L.) Pierre and Clerodendrum viscisum (Vent.) on the catfish, Heteropneustes fossilis (Bloch). Journal of Asiatic Society of Bangladsh, Science. 2013; 39(1):105-115.

12. Akinsanya B, Utoh OU, Ukwa UD. Toxicological, phytochemical and anthelminthic properties of rich plant extracts on Clarias gariepinus. The Journal of Basic and Applied Zoology. 2016; 74:75-86. http:// dx.doi.org/10.1016/j.jobaz.2016.09.003

13. Audu BS, Omirinde JO, Gosomji IJ, Wazhi PE. Histopathological changes in the gill and liver of Clarias gariepinus exposed to acute concentrations of Vernonia amygdalina. Animal Research Internationai. 2017; 14(1):2576-2587. www.zoo-unn.org

14. Abalaka SE, Fatihu MY, Ibrahim NDG, Kazeem HM. Histopathological changes in the gills and skin of adult Clarias gariepinus exposed to ethanolic extract of Parkia biglobosa pods. Basic and Applied Pathology. 2010; 3(4):109-114.

15. Nasiruddin M, Azadi MA, Jahan A. Histopathological changes in gill, liver and intestine of Heteropneustes fossilis (bloch) treated with three dry seed extracts. Journal of Asiatic Society of Bangladsh, Science. 2012; 38(2):217-226. http://doi.org/10.3329/jasbs.v38i2.15612

16. Rezende FP, Pascoal LM, Vianna RA, Lanna EAT. Sedation of Nile tilapia with essential oils: tea tree, clove, eucleptus, and mint oils. Review of Caatinga. 2017; 30(2):479486.

17. American Public Health Association (APHA). Standard Methods for Examination of Water and Wastewater. 15th Ed. Washington D.C. USA. 1985; P. 113.

18. American Public Health Association (APHA). Standard Methods for Examination of Water and Wastewater. Washington. USA. 1998.

19. Drury R Wallington E. Histological Technique. 1967; 4th edition, Oxford University Press, USA, 279-280.

20. Avwioro OG. Staining reactions of microwave processed tissues compared with conventional paraffin wax processed tissues. European Journal of Experimental Biology. 2011; 1 (1):57-62.

21. Devi PA, Padmavathy P, Aanand S, Aruljothy K. Review on water quality parameters in freshwater cage fish culyure. International Journal of Applied Research. 2017; 3(5):114120. www.allresearchjournal.com

22. Bolorunduro PI, Abdullah AY. Water quality management in fish culture, National Agricultural Extension and Research Liaison Services, Zaria, Extension Bulletin No. 98, 1996; 10.

23. Adedeyi DO, Odo KE. Acute toxicity and haematology of Clarias gariepinus exposed to selenium, International Journal of Agriculture. 2017; 7(9): 64-70. http:// doi.org/10.5376/ija.2017.07.0009

24. Kasi M, Umah R, Muralikrishnan S, Xavier R, Kathiresan S. Effect of different feed application rate on growth, survival and cannibalism of African catfish, Clarias gariepinus fingerlings. Emirate Journal of Food and Agriculture. 2011; 23 (4):330-337. http://ejfa.info/

25. Audu BS, Adamu KM, Ufodike EBC. Behavioural response and opercula ventilation rate of Nile Tilapia (Oreochromis niloticus) fingerlings after anaesthesia with aqueous crude leaves extract of marijuana (Cannabis sativa). Applied Science Research Journal. 2013; 1(2):66-77.

26. Anonymous Nile Tilapia (Oreochromis niloticus). n.d. www.cabi.org

27. David C, Water quality in aquaculture. 2012. http:// article.extension.org

28. Ajima MNO, Audu BS, Mane AM, Okeke L, Varghese T. Alteration in activities of some metabolic enzymes and haematological profile of African catfish, Clarias gariepinus chronically treated with urea fertilizer. Research in Environmental Life Science. 2017; 10(2):129-134. http:// rels.comxa.com

29. Alhou B, Issiaka Y, Adamou MM, Abdou I. Effects of Balanites aegyptiaca on tadpoles and Oreochromis niloticus. Journal of Applied Bioscience. 2016; 1:9220-9226. http:// dx.doi.org/10.4314/jab.v97i1.7

30. Ngugi CC, James RB, Bethuel OO. A New Guide to Fish Farming in Kenya. 2007; Oregon State University, USA. pp 42-55.

31. Becker AG, Cunha MA, Garcia LO, Zeppenfeld CC, Parodi TV, Maldaner G, Morel AF, Baldisserotto B. Efficacy of eugenol and the methanolic extract of Condalia buxifolia during the transport of the silver catfish, Rhamdia quelen. Neotropical. Ichthyology. 2013; 11(3):675-681. dx.doi.org/10.1590/S1679-62252013000300021

32. Naeemi A, Jamili S, Shabanipour N, Mashinchian A, Shariati FS. Histopathological changes of fill, liver, and kidney in Caspian kutum exposed to linear alkylbenzene. Iranian Journal of Fisheries Science. 2013; 12(4): 887-897. 
33. Gulhan FM, Talas SZ, Orun EK. The effects of propolis on gill, liver, muscle tissues of rainbow trout (Oncorhynchus mykiss) exposed to various concentrations of cypermethrin. Iranian Journal of Fisheries. 2014; 13(3):684-701.

34. Adebola K, Ayo F. Histological changes in liver, gills and kidney of catfish (Heterobranchus bidorsalis) exposed to cypermethrin concentration. International Journal of Histology and Cytology. 2014;1(4):31-36. www.internationalscholarsjournals.org

35. Thophon S, Kruatrache M, Upatham ES, Pokethitiyook P, Sahaphong S, Jaritkhuan S. Histopathological alterations of white seabass Lates calcarifer, in acute and subchronic cadmium exposure. Environmental Pollution. 2003; 121:307-320.

36. Takashima F, Hibiya T. An atlas of fish histology: normal and pathological features, Lubrecht \& Cramer Limited, 2nd edition. 1995; Tokyo, Kodansha 213pp. www.amazon.com

37. Al-Yousuf MH, El-Shahawi MS, Al-Ghais SM.Trace metals in liver, skin and muscle of Lethrinus lentjan fish species in relation to body length and sex. Science of the Total Environment. 2000; 256:87-94.

38. Hadi AA, Alwan SF. Histopathological changes in gills, liver and kidney of fresh water fish, Tilapia zillii, exposed to aluminium. International Journal of Pharmacy \& Life Sciences. 2012; 3(11): 2071-2051.

39. Faheem M Lone KP. Oxidative stress and histopathologic biomarkers of exposure to bisphenol-A in the freshwater fish, Ctenopharyngodon idella. Brazilian Journal of Pharmaceutical Sciences. 2017; 53(3):7003-7012. http:// dx.doi.org/10.1590/s2175-97902017000317003

40. Faheem M Lone KP. Oxidative stress and histopathologic biomarkers of exposure to bisphenol-A in the freshwater fish, Ctenopharyngodon idella. Brazilian Journal of Pharmaceutical Sciences. 2017; 53(3):7003-7012. http:// dx.doi.org/10.1590/s2175-97902017000317003 